\title{
STUDIES ON LUMINESCENCE. ON THE SUBOCULAR LIGHT-ORGANS OF STOMIATOID FISHES
}

\author{
By J. A. C. Nicol \\ The Plymouth Laboratory
}

(Text-figs. I-IO)

Many stomiatoid fishes possess a peculiar light-organ below and behind the eye, as well as other kinds of photophores. This light-organ, of diagnostic importance, is termed the subocular, postocular or cheek-organ. Stomiatoid fishes, suborder Stomiatoidei, form a suborder of the Isospondyli. Subocular organs are found in the following groups:

Superfamily Stomiatoidae

Stomiatidae and Chauliodontidae

Superfamily Astronesthoidae (= Gymnophotodermi)

Astronesthidae, Melanostomiatidae and Idiacanthidae.

Over the course of the past 8 years I have collected specimens of species belonging to each of the above families, and this material has made possible a comparative study of the subocular organs of the Stomiatoidei.

\section{MATERIALS AND METHODS}

Specimens of stomiatoid fishes were obtained from deep-sea catches of the R.R.S. 'Discovery II' and R.V. 'Sarsia'. I am indebted to the Director of the National Institute of Oceanography for the former material. The following species were examined.

Stomiatidae

Stomias brevibarbatus Ege, I9I8. One specimen, 'Discovery' station No. 3354 .

S. ferox Reinhardt (Zugmayer, I9II; Ege, I9I8). Four specimens, 'Sarsia' stations No. 7/1957, No. II (Kon \& Fisher)/1959, No. I5/1959. Chauliodontidae

Chauliodus sloani Schneider (Regan \& Trewavas, 1929). One specimen, 'Discovery' station No. 305I.

Astronesthidae

Astronesthes elucens Brauer (Parr, 1927). Two specimens, 'Sarsia' stations Nos. 23/1957, I4/1959. 
Astronesthes richardsoni Poey (Parr, 1927). One specimen, 'Sarsia' station No. 12/1959.

Melanostomiatidae

Photostomias guernei Collett (Parr, 1927). One specimen, 'Discovery' station No. 3254 .

Idiacanthidae

Idiacanthus fasciola Peters (Parr, 1927). One specimen, 'Discovery' station No. 3354.

\section{Station details}

'Discovery' station No. 3051. 26 August 1952. $39^{\circ} 29^{\prime}$ N., $9^{\circ} 50^{\prime}$ W. TYF oblique. Estimated depth $700 \mathrm{~m}$.

'Discovery' station No. 3354. See Nicol (1958).

'Sarsia' station No. 23/1957. See Nicol (1958).

'Sarsia' station No. $7 / 1957.20$ June 1957. $47^{\circ} \circ 7^{\prime}$ N., $6^{\circ} 06^{\prime}$ W. Isaacs Kidd trawl oblique. $\mathrm{I} 800 \mathrm{~m}$ of wire out.

'Sarsia' station No. II (Kon \& Fisher)/1959. II October, 1959. $44^{\circ}$ I9' $^{\prime}$, $3^{\circ} 56^{\prime}$ W. Isaacs Kidd trawl oblique. $1800 \mathrm{~m}$. of wire out.

'Sarsia' station No. 12/1959. 9 June 1959. $46^{\circ} 59^{\prime}$ N., $6^{\circ}$ o3' W. to $47^{\circ}$ or' N., $6^{\circ}$ oo' W. Isaacs Kidd trawl oblique. $915 \mathrm{~m}$ of wire out.

'Sarsia' station No. I4/1959. Io June 1959. $46^{\circ} 59^{\prime} \mathrm{N}$., $6^{\circ}$ o2' W. to $46^{\circ} 57^{\prime} \mathrm{N}$., $6^{\circ} \mathrm{o}^{\prime}$ W. Isaacs Kidd trawl oblique. $1830 \mathrm{~m}$ of wire out.

'Sarsia' station No. I5/1959. Io June I959. $46^{\circ} 47^{\prime}$ N., $6^{\circ}$ o3' W. Isaacs Kidd trawl oblique. $1829 \mathrm{~m}$ of wire out.

\section{Treatment}

All the stomiatoid fishes listed above were dead when taken from the bucket, or were obtained from preserved collections. They were preserved in formalin and the majority were post-fixed-in Heidenhain's Susa, Bouin's or Zenker's fluids. When necessary, decalcification was carried out with weak formic acid. Embedding media were paraffin wax, polyester wax and celloidin.

Stains used were Ehrlich's haematoxylin and eosin plus Biebrich scarlet; Ehrlich's haematoxylin and eosin plus azure II; a modification of Masson's trichrome consisting of iron haematoxylin, aniline blue and Biebrich scarlet (M I); a modification of Masson's trichrome consisting of iron haematoxylin, fast green FCF and Biebrich scarlet (M2), iron haematoxylin and orange G; Heidenhain's azan; Holmes's silver.

\section{DESCRIPTIVE HISTOLOGY}

In all the stomiatoid fishes examined the suborbital light-organs have the following fundamental plan. A dense mass of photogenic tissue lies underneath the skin. The skin over the light-organ forms a clear window and is separated from the light-organ proper by a narrow space. Investing the back (i.e. the internal surface) of the photogenic mass is an inner tunic or reflector, then a layer of dark pigment. A muscle inserted on the light-organ runs behind and underneath the organ.

The dimensions of the light-organs, and of their component parts, given in the following sections, refer to the specimens which I have examined and 
are presented merely to give some idea of the degree of magnitude of the structures under consideration. Since deep-sea fish, in illustrations, often seem much larger than they actually are, I have shown the size range of each species, as given in the pertinent literature.

The light-organs of most of the species examined are very similar to each other, the chief exception being Idiacanthus. To obviate repetition, the subocular organ of Astronesthes elucens, selected as a representative type, is described in detail. Peculiarities and differences encountered in the lightorgans of the other species are then presented.

A. elucens Brauer. $146-197 \mathrm{~mm}$. The subocular organ is a small, oval, white structure lying below and behind the eye. On one side of the head of one fish there is a small accessory organ in front of the main subocular organ. External dimensions are $1.5 \mathrm{~mm}$ long and $0.8 \mathrm{~mm}$ high. The white surfaces of the organs are exposed, i.e. the organs are open in both specimens examined.

The subocular organ proper, i.e. the photogenic mass plus reflector, is beaker-shaped in transverse section (Fig. I). The outer surface is convex. Dimensions are $0.7 \mathrm{~mm}$ high and $0.65 \mathrm{~mm}$ deep.

The skin over the light-organ is I0-20 $\mu$ thick. It consists of a thin epidermis made of stratified squamous epithelial cells, and an underlying dense dermis staining with aniline blue. A space between the dermis and the light-organ ranges from $\mathrm{I} 2$ to $100 \mu$ across.

A thin sheath of connective tissue over the outer face of the photogenic mass is 5-10 $\mu$ thick. It consists of a dense layer of fibres staining with aniline blue. A little loose connective tissue, also staining faintly with aniline blue, lies over this outer sheath. The outer sheath and loose connective tissue are continuous with loose connective tissue on either side of the light-organ.

The centre of the light-organ is occupied by a mass of glandular photogenic tissue. This is a compact accumulation of cells arranged in cords or circlets. The photocytes are polygonal in section, about Io $\mu$ in diameter, and each contains a central oval nucleus. Around the circumference of the photogenic mass the photocytes appear elongate, with the nucleus in the peripheral half of the cell (i.e. the half of the cell towards the circumference of the photogenic mass). The cytoplasm is granular and stains as follows: $M_{\mathrm{I}}$, purple (same colour as muscle); eosin and Biebrich scarlet, red; eosin-azure, centre of cell pink, periphery blue; orange $G$, orange. In photocytes stained with Ehrlich's haematoxylin and eosin, cytoplasmic differentiation appears as follows. Peripheral photocytes have a homogeneous basic cytoplasm, staining blue with haematoxylin below the nucleus. Above the nucleus the cytoplasm is packed with eosinophilic granules. More central cells have a blue peripheral band, tenuous to very broad, about the cell periphery. Within this is red eosinophilic granular material. These apparent differences may result from photocytes being cut at different levels. In this event all photocytes have a homogeneous basiphilic ground cytoplasm, conspicuous at the cell periphery 
and below the nucleus; the centre of the cell above the nucleus is loaded with acidophilic granules.

The reflector layer, backing the photogenic mass, is $30-60 \mu$ thick. It contains very dense tissue which shines blue by reflected light, and contains some kind of reflecting pigment. By transmitted light the unstained tissue appears light yellow-brown. The reflecting pigment is missing in many

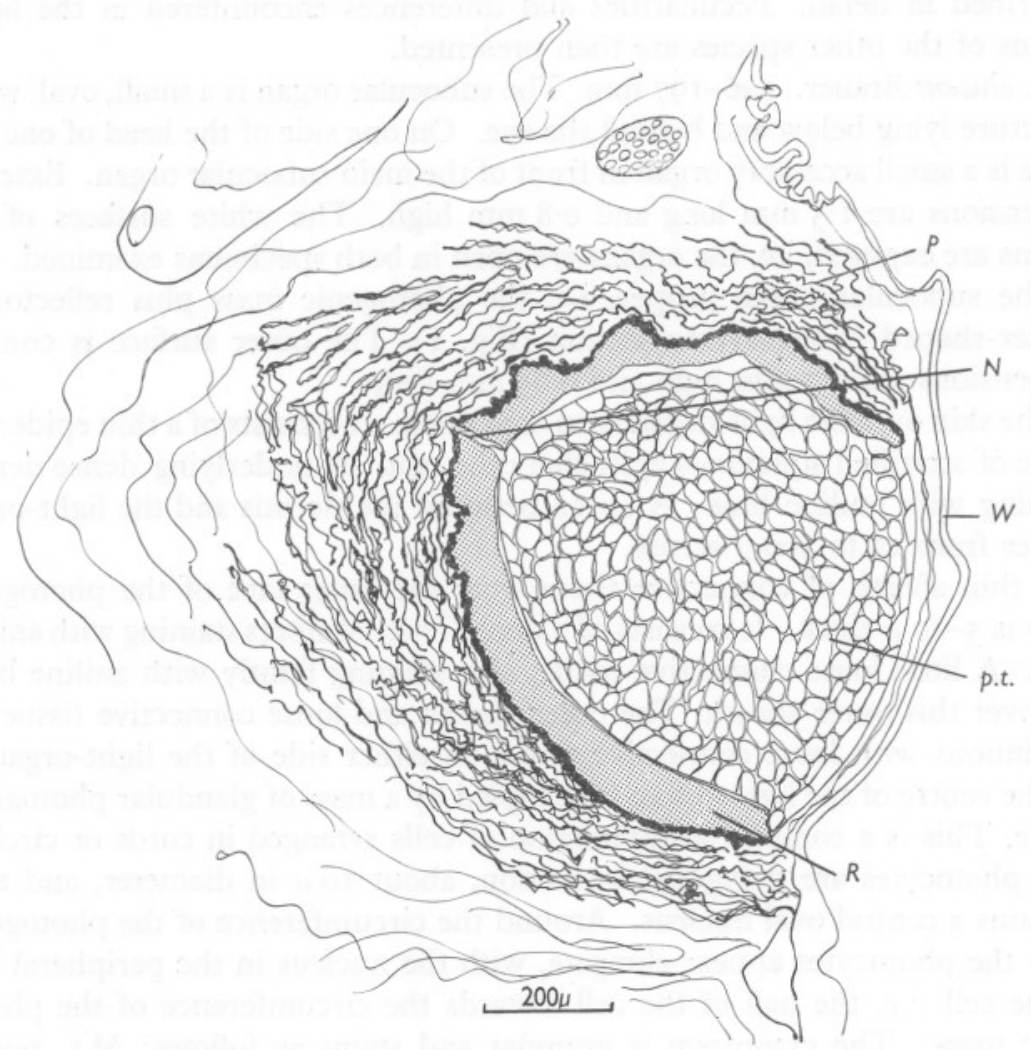

Fig. I. Transverse vertical section through a subocular light-organ of Astronesthes elucens. $(N$, nerve. $P$, pigment. p.t., photogenic tissue. $R$, reflector. $W$, clear window.

sections, dissolved out, perhaps, by some of the staining reagents. The reflecting layer appears to consist of long thin cells. Nuclei are elongate, thin and fusiform. Staining affinities of the tissue are poor: light blue with aniline blue; faint pink with eosin. Blood vessels and at least one nerve penetrate the reflector to supply the photogenic tissue within.

Behind (i.e. internal to) the reflector is a wide area of very loose connective tissue containing numerous pigmented cells. These possess dark yellow-brown 
granules. Some pigmented cells are conspicuously oriented as a unicellular dark sheet immediately behind (internal to) the reflector.

Below the reflector there is a cleft in the pigmented connective tissue, this cleft being continuous with the space in front of the light-organ. There are pigmented cells in the loose connective tissue below the cleft. A long straplike muscle runs down through the pigmented tissue at the back of the organ, and is inserted in the loose connective tissue underneath the organ, towards the external surface, as described by Brauer (1904, I908). This muscle passes dorsally, behind the eye, between two sheets of the $\mathrm{m}$. adductor mandibulae, to its origin on the hyomandibula. It is a striated muscle having more slender fibres than the $\mathrm{m}$. adductor mandibulae, from which it is possibly derived.

Astronesthes richardsoni Poey. I50-234 mm. The subocular organs of this fish are rather large, $3.2 \mathrm{~mm}$ long and $\mathrm{I} .5 \mathrm{~mm}$ high. Each organ is oblong in shape and shows as a conspicuous white object against the surrounding skin. In this specimen both organs are exposed, i.e. they are in the 'open' position.

The light-organ proper is lenticular in section, the outer surface being particularly convex (Fig. 2). Dimensions are $\mathrm{I} .8 \mathrm{~mm}$ high and I mm thick. A thin connective tissue sheath covers the outer surface of the photogenic mass.

The photogenic tissue is a dense mass of closely packed glandular cells. These are aggregated into groups, appearing as bands or rosettes in section. They are polyhedral in shape, about $\mathrm{I} 2 \mu$ in size, except at the outer margin of the photogenic mass, described below. The cytoplasm is granular, and generally stains with eosin and orange G. An outer margin or marginal crescent-shaped area of some cells is darker than the centre, and has taken up some haematoxylin.

On the front of the photogenic mass, beginning at the outer margin of the reflector, the photogenic tissue shows another pattern. Externally there is a regular unicellular layer of glandular cells, forming a simple columnar or cuboidal epithelium. The nuclei lie at the outer ends of the cells, against the external surfaces. There is a granular eosinophilic cytoplasm, which stains less intensely in the external region of the cell, and more intensely internally. Inside this layer is a region, one or two cells deep, in which the photocytes appear highly vacuolated, each cell containing a huge vacuole or a poorly staining globular area. With Heidenhain-azan, the outermost cells of the photogenic mass stain blue.

The inner tunic contains reflecting pigment. Nerves and blood vessels penetrate the pigment and reflector layers to invade the photogenic tissue. The muscle to the light-organ is inserted in the connective tissue sheath over the external surface of the photogenic mass.

Stomias brevibarbatus Ege. 39-I00 $\mathrm{mm}$ (excluding caudal fin). In the specimen available, both subocular organs are rotated equally so that most of the light-emitting surface faces downwards and is concealed; the exposed surface is dark (Fig. 3). 
In a transverse section (vertically across the head) the photogenic mass plus tunic is almost circular, $372 \mu$ high and $348 \mu$ deep (Fig. 4). The clear skin over the organ consists of thin stratified squamous epithelium and a little loose connective tissue.

The photocytes are 6-8 $\mu$ in size, polygonal, and aggregated into cords or bands. The cytoplasm is dense, granular and acidophilic. No reflecting pig-

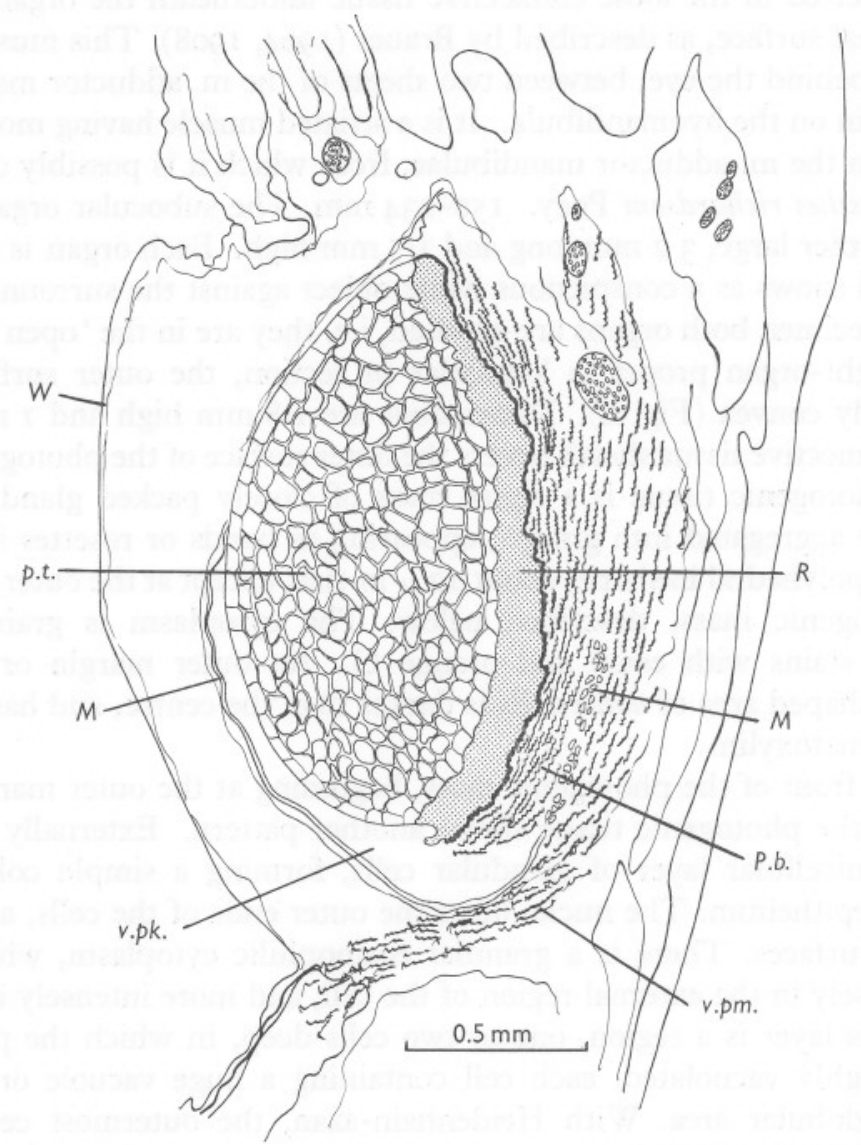

Fig. 2. Transverse vertical section through a subocular light-organ of Astronesthes richardsoni. $M$, muscle. P.b., pigment backing. p.t., photogenic tissue. R, reflector. v.pm. ventral pigment. v.pk., ventral pocket. $W$, clear window.

ment was observed in the inner tunic. Below the photogenic mass is a cleft or pocket in the connective tissue and underneath the cleft are several layers of pigmented cells.

Stomias ferox Reinhardt. 50-170 mm (exclusive of caudal fin). Four specimens were available, two large and two small. In the two larger specimens 
the subocular light organs were in the exposed position, i.e. the light-emitting surfaces faced outwards. The organ appeared as a white ovate or pyriform area in a densely pigmented surround. Dimensions were $0.68 \mathrm{~mm}$ across and $0.96 \mathrm{~mm}$ high, and $0.60 \mathrm{~mm}$ across and $0.85 \mathrm{~mm}$ high. In the two smaller specimens the subocular light-organs were not visible externally.

In vertical section the photogenic mass is bowl-shaped, with a strongly convex inner, and a slightly convex outer, surface (Fig. 5). Dimensions of the photogenic mass plus pigmented backing are $0.87 \mathrm{~mm}$ tall and $0.48 \mathrm{~mm}$ thick. Investing the photogenic mass is a thin sheath of connective tissue. The photocytes have a clear ground cytoplasm and contain many small granules, about $\mathrm{I} \mu$ in size, staining with orange $\mathrm{G}$ and azocarmine.

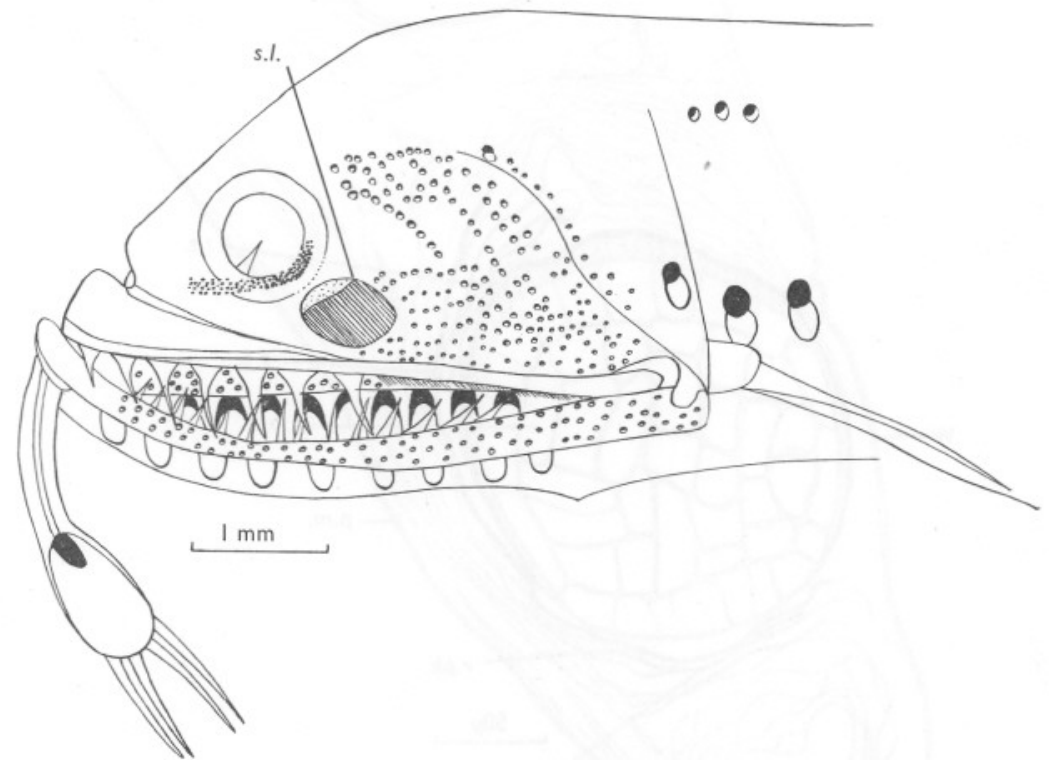

Fig. 3. Head of Stomias brevibarbatus. Subocular light-organs (s.l.) mostly occluded (rolled downwards.)

Chauliodus sloani Schneider. 20-270 mm (excluding caudal fin). Both subocular organs have the light-emitting surface exposed. Dimensions are $0.38 \mathrm{~mm}$ long and $0.29 \mathrm{~mm}$ high, including the narrow pigmented surround.

In transverse section, the photogenic organ proper (photogenic mass plus inner tunic and pigmented sheath) is beaker shaped, with a convex outer surface (Fig. 6). It is $384 \mu$ high and $325 \mu$ thick. The photogenic cells are elongate, radiating inwards towards the centre from the margin. They are about $6 \mu$ in diameter, the length is uncertain, perhaps $130-140 \mu$. The cytoplasm is packed with granular inclusions staining red with Biebrich scarlet. 
The internal tunic consists of loosely disposed thin cells, having their longitudinal axes lying parallel to the inner (internal) surface of the photogenic mass. According to Brauer (1904, 1908), this is a reflector layer. Pigment cells form a dense mantle immediately against the light-organ. Beyond this region the pigment cells are arranged more loosely. A ventral screen of pigment cells serves to occlude the emitting surface when the photogenic organ is rotated downwards.

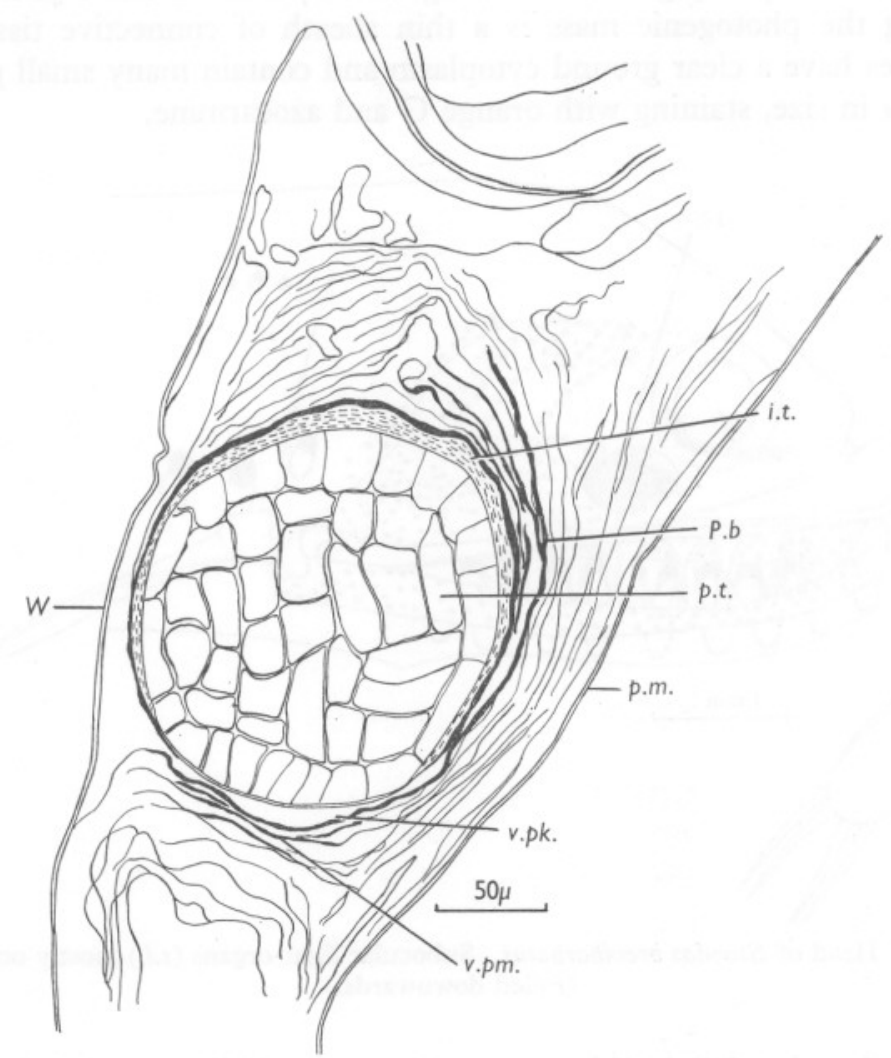

Fig. 4. Transverse vertical section through a subocular light-organ of Stomias brevibarbatus. i.t., inner tunic. P.b., pigment backing. p.m., pharyngeal mucosa. p.t., photogenic tissue. $v$.pm., ventral pigment. v.pk., ventral pocket. $W$, clear window.

A band-like muscle, connected to the light-organ, arises dorsally on a long aponeurosis from the hyomandibular bone. The muscle extends ventrally between two sheets of the muscularis adductor mandibulae, then runs through connective tissue obliquely outwards below the light-organ. It is inserted, behind the light-organ, on a long tendon, staining with Light Green (Fig. 7). The tendon runs between pigment cells behind (i.e. internal to) and below 
the light-organ, and is inserted on the ventro-lateral face of the latter. This muscle-band, serving the light-organ, retains its identity throughout its course; its fibres are striated and smaller than those of the $\mathrm{m}$. adductor mandibulae. It is muscle $\mathrm{mm} 6$ of Tchernavin (1953), who traced it to the dorsal side of the maxillary division of $\mathrm{m}$. add. mandibulae. Tchernavin considered that the photophore-muscle exposed the light-organ, i.e. it rotated it so that the light-emitting surface came to face outwards. This statement

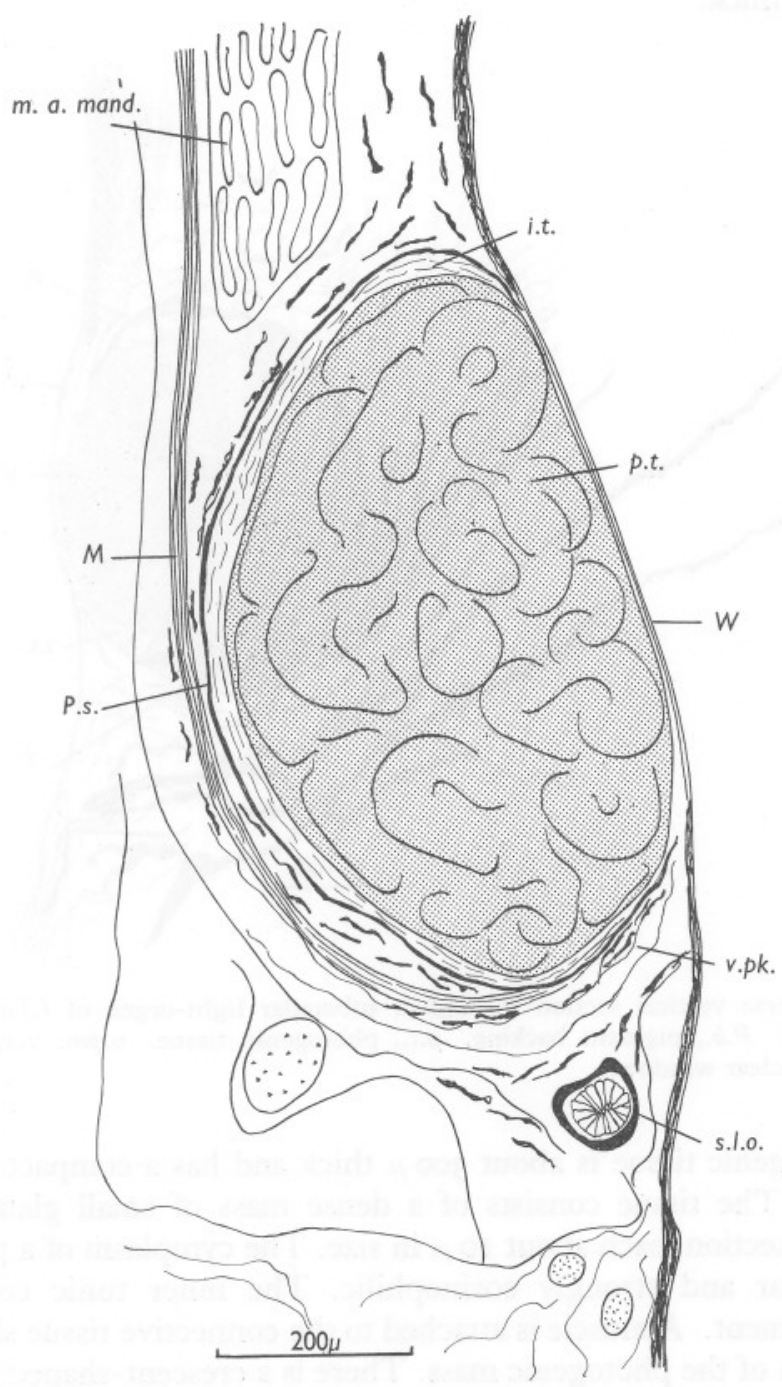

Fig. 5. Transverse vertical section through a subocular light-organ of Stomias ferox. i.t., inner tunic. $M$, muscle. m. a. mand., muscularis adductor mandibulae. P.s., pigment sheath. p.t., photogenic tissue. s.l.o., small light-organ. v.pk., ventral pocket. W, clear window. 
suggests that Tchernavin believed that the muscle was inserted on the dorsal side of the organ. In fact, since the tendon connecting the muscle to the lightorgan is inserted on the ventral side of the organ, contraction of the muscle should pull the outer face of the organ downwards, thus occluding the lightemitting surface.

Photostomias guernei Collett. 38-106 mm (excluding caudal fin). The subocular organ is oval-shaped; its dimensions are $0.4 \mathrm{~mm}$ high, $0.8 \mathrm{~mm}$ long and $0.4 \mathrm{~mm}$ thick.

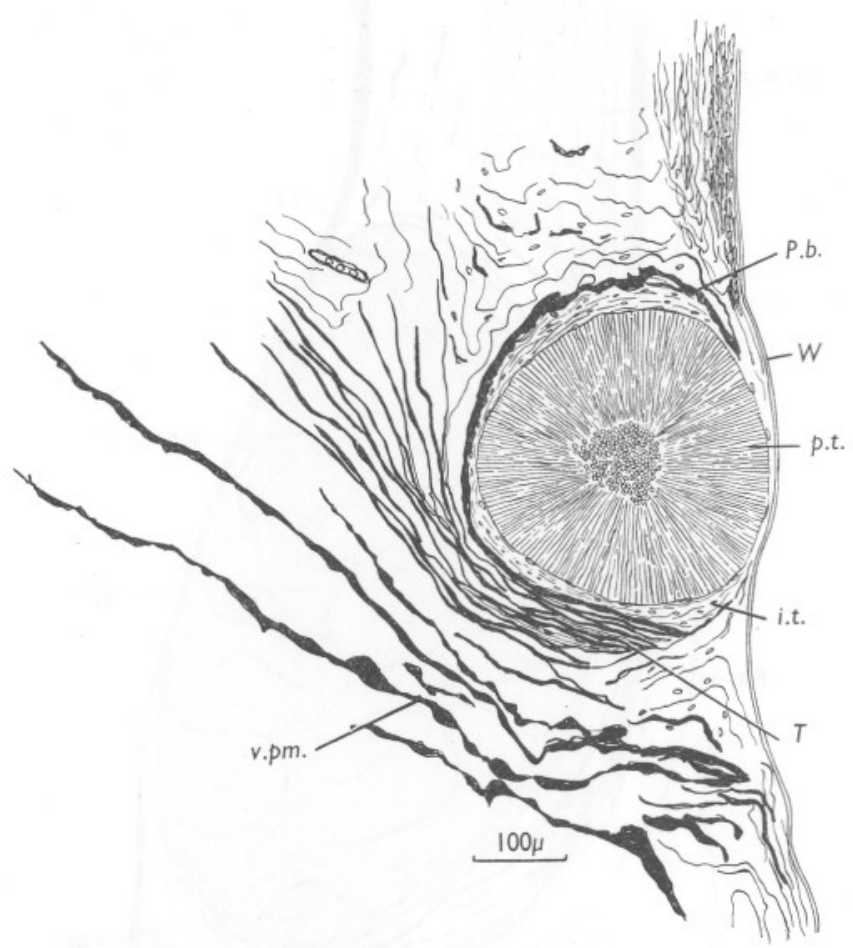

Fig. 6. Transverse vertical section through a subocular light-organ of Chauliodus sloani. i.t., inner tunic. P.b., pigment backing. p.t., photogenic tissue. v.pm. ventral pigment. $T$, tendon. $W$, clear window.

The photogenic tissue is about $300 \mu$ thick and has a compact appearance (Figs. 8, 9). The tissue consists of a dense mass of small glandular cells, polygonal in section, each about ro $\mu$ in size. The cytoplasm of a photocyte is finely granular and strongly eosinophilic. The inner tunic contained no reflecting pigment. A muscle is attached to the connective tissue sheath in the ventral region of the photogenic mass. There is a crescent-shaped cleft or gap in the loose connective tissue beneath the light-organ. The depth of this cleft is about equal to the height of the external face of the light-organ. The 
connective tissue beneath the cleft (and above the mandible) contains black pigment cells.

Idiacanthus fasciola Peters. $80-225 \mathrm{~mm}$ (excluding caudal fin). The subocular light-organs are exposed. Each organ is oblong in shape, $0.25 \mathrm{~mm}$ long and $0.13 \mathrm{~mm}$ high. These dimensions include the pigmented surround.

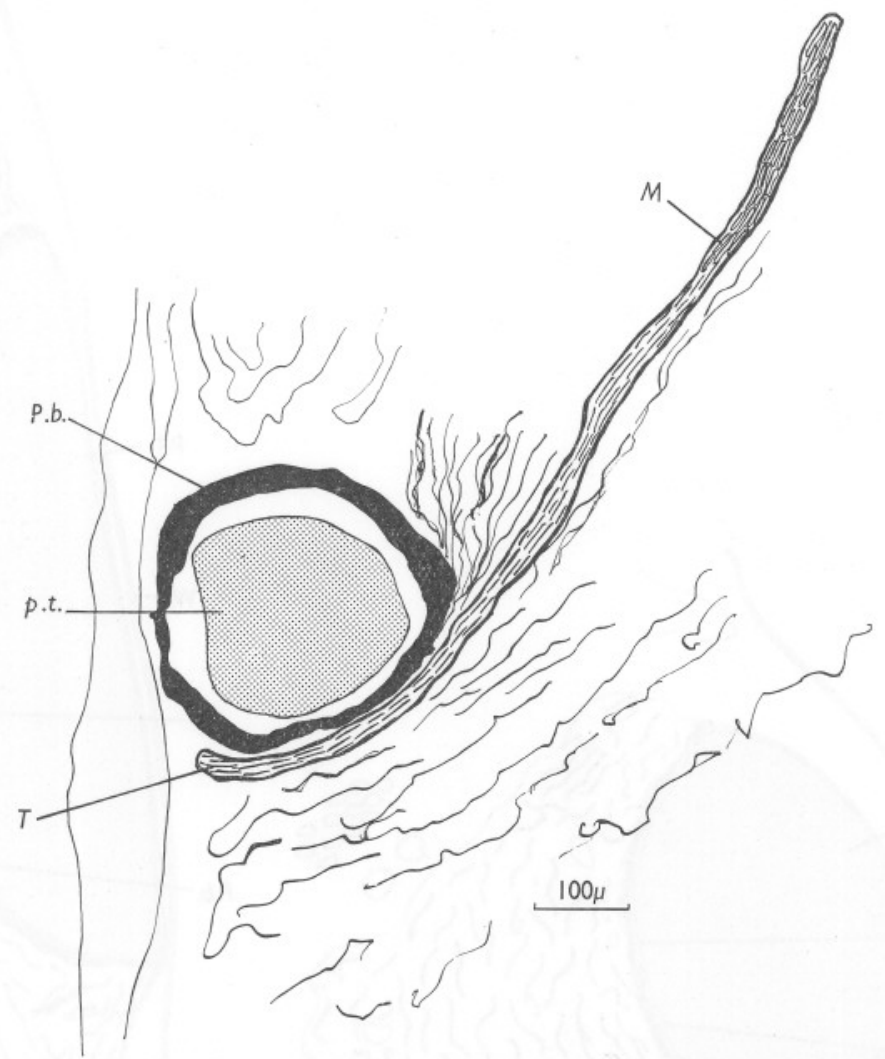

Fig. 7. Transverse vertical section through the head of Chauliodus sloani, showing the disposition of tissues in the vicinity of the subocular light-organ. $M$, muscle. P.b., pigment backing. p.t., photogenic tissue. $T$, tendon.

In section the photogenic mass is subspherical, oblate on the outer surface. Dimensions (including pigment tunic) are $96 \mu$ high by $99 \mu$ thick Fig. I0).

The photogenic mass is packed with photocytes. The photocytes are polygonal in shape, $5-9 \mu$ in size. The cytoplasm is granular; the granules are acidophilic, staining with orange $\mathrm{G}$. The internal tunic contains elongate cells having little staining affinity; according to Brauer (1908), this is a reflector layer. 


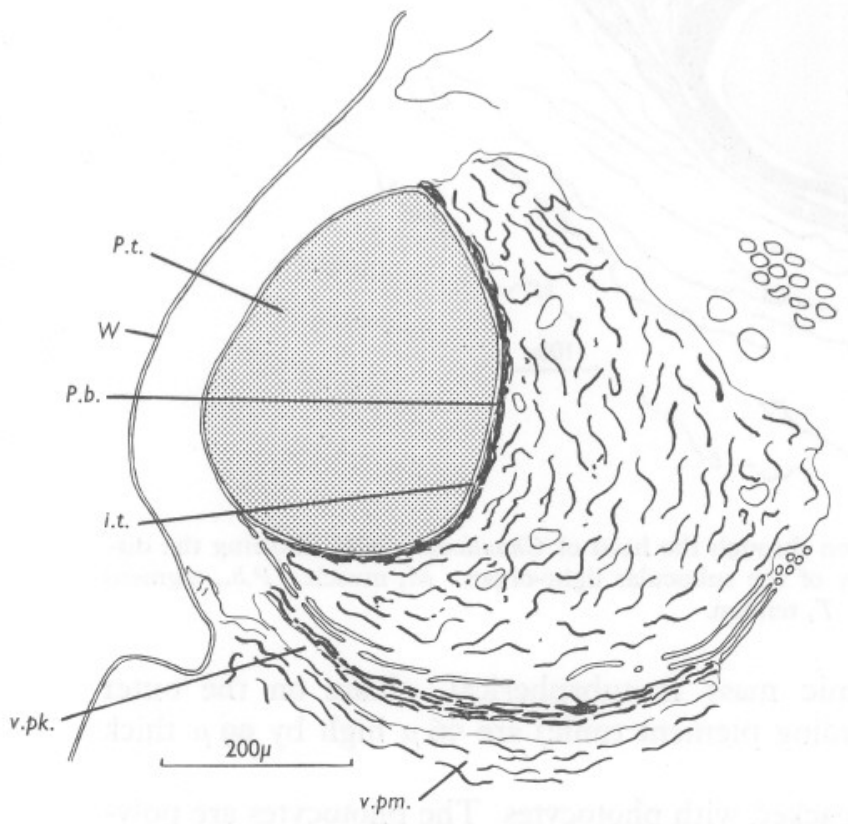

Fig. 8

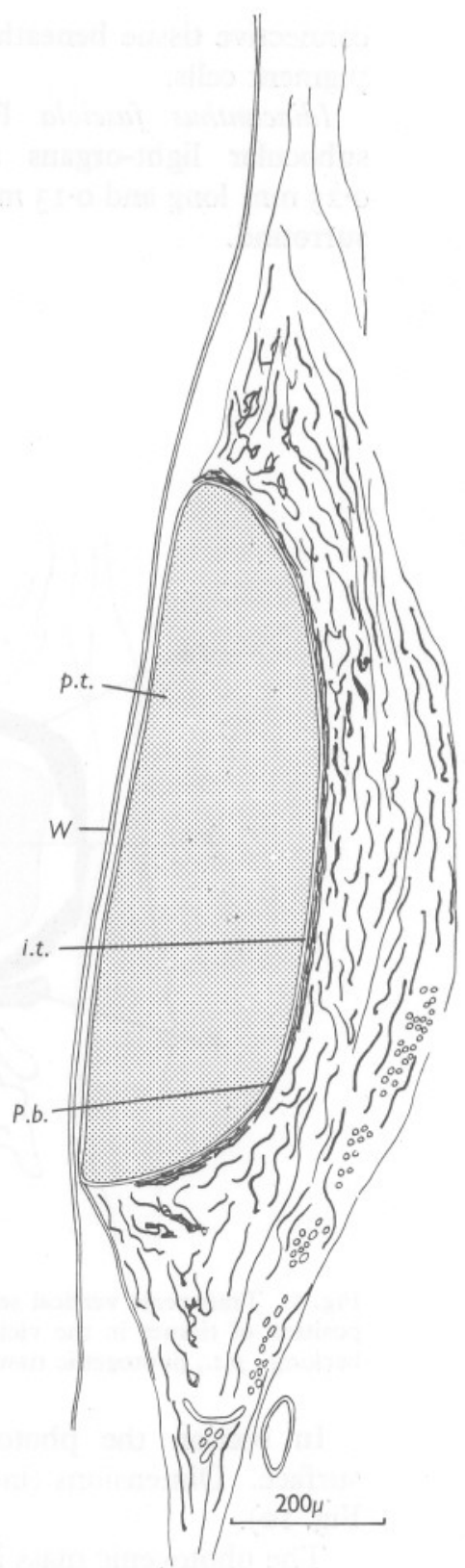

Fig. 9

Fig. 8. Transverse vertical section through a subocular light-organ of Photostomias guernei. i.t., inner tunic. P.b., pigment backing. p.t., photogenic tissue. v.pk., ventral pocket. $W$, clear window.

Fig. 9. Transverse longitudinal section through a subocular light-organ of Photostomias guernei. i.t., inner tunic. P.b., pigment backing. p.t., photogenic tissue. $W$, clear window. 


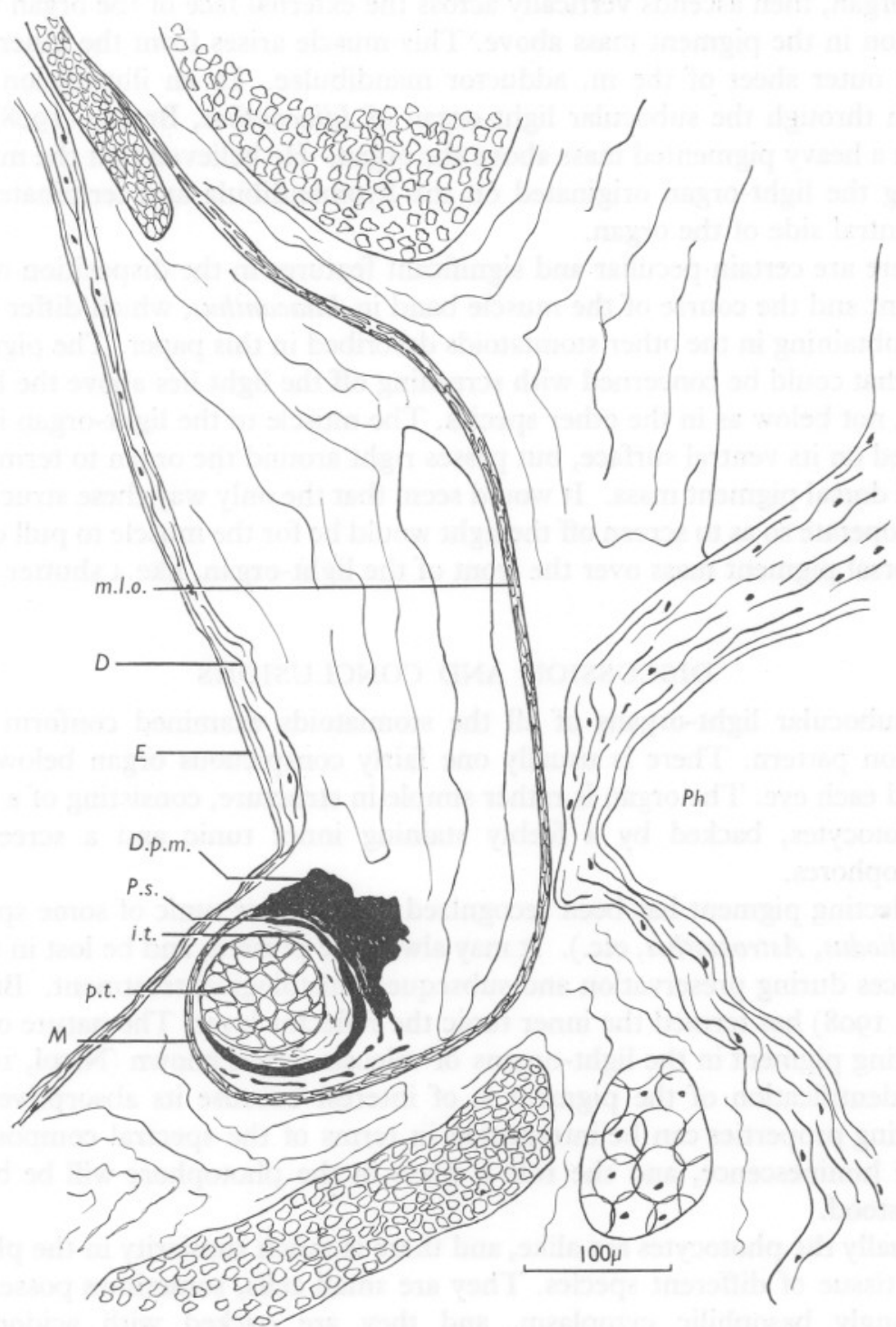

Fig. Io. Transverse vertical section through the head of Idiacanthus fasciola, showing the disposition of tissues in the vicinity of the subocular light-organ. D, dermis. D.p.m. dorsal pigmented mass. E., epidermis. i.t., inner tunic. M, muscle. m.l.o., muscle to light-organ. Ph., pharynx. P.s., pigment sheath. p.t., photogenic tissue. 
Above the light-organ there is a dense and thick mass of pigmented tissue. A narrow strap-like muscle runs down along the inner surface and below the light-organ, then ascends vertically across the external face of the organ to an insertion in the pigment mass above. This muscle arises from the inner face of the outer sheet of the $\mathrm{m}$. adductor mandibulae. In an illustration of a section through the subocular light-organ of Idiacanthus, Brauer (I908) has shown a heavy pigmented mass above the organ. He believed that the muscle serving the light-organ originated on the hyomandibula and terminated on the ventral side of the organ.

There are certain peculiar and significant features in the disposition of the pigment and the course of the muscle band in Idiacanthus, which differ from those obtaining in the other stomiatoids described in this paper. The pigment mass that could be concerned with screening off the light lies above the lightorgan, not below as in the other species. The muscle to the light-organ is not inserted on its ventral surface, but passes right around the organ to terminate on the dorsal pigment mass. It would seem that the only way these structures could operate so as to screen off the light would be for the muscle to pull down the dorsal pigment mass over the front of the light-organ, like a shutter.

\section{DISCUSSION AND CONCLUSIONS}

The subocular light-organs of all the stomiatoids examined conform to a common pattern. There is usually one fairly conspicuous organ below and behind each eye. The organ is rather simple in structure, consisting of a mass of photocytes, backed by a feebly staining inner tunic and a screen of melanophores.

Reflecting pigment has been recognized in the inner tunic of some species (Chauliodus, Astronesthes, etc.). It may always be present, and be lost in some instances during preservation and subsequent histological treatment. Brauer (1904, 1908) has termed the inner tunic the reflector layer. The nature of the reflecting pigment in the light-organs of teleosts is not known (Nicol, 1957). The identification of the pigment is of interest because its absorptive and reflecting properties can be interpreted in terms of the spectral composition of the luminescence, and the role it plays in the photophore will be better understood.

Usually the photocytes are alike, and there is much similarity in the photogenic tissue of different species. They are small cells, sometimes possessing a strongly basophilic cytoplasm, and they are packed with acidophilic granules. In one species, viz. Astronesthes richardsoni, cytological differentiation within the photogenic tissue is recognizable.

There is no lens system for focusing the light, nor for enlarging the apparent size of the source. When a reflector is present, it is possible that it acts to some extent as a parabolic mirror. 
A muscle goes to each light-organ. It arises from the hyomandibula, or from the muscularis adductor mandibulae, and runs down behind the eye inside and below the light-organ. It is usually inserted in the connective tissue sheath on the outer surface or ventro-lateral surface of the photogenic mass. In Chauliodus the muscle arises from an aponeurosis attached to the hyomandibula, and is inserted on a tendon which goes to the ventral surface of the light-organ. Its action appears to be the same as in the other species in which the muscle extends over the entire path from hyomandibula to lightorgan. From the manner in which this muscle is arranged it is probable that it pulls the outer face of the light-organ downwards. Brauer (1904, 1908) recognized this muscle in a number of different stomiatoids (Chauliodus, Astronesthes, etc.), and he also believed that it rotated the light organ ventrally. Since there is a black pigmented layer in the connective tissue below the lightorgan, this action serves to screen the light-emitting surface.

Idiacanthus is peculiar in that a pigment layer lies above the light-organ, and the muscle passes upwards, in front of (i.e. external to) the light-organ, to be inserted in this pigment layer. It seems that the muscle pulls the pigment down in front of the light-organ of Idiacanthus and does not move the photogenic mass.

Confirming Tchernavin (1953), I have found no antagonist to the muscle mentioned above. It is not apparent how the light-organ (or shutter in the case of Idiacanthus) is rotated to a position so that the light-emitting surface is exposed. Suggestions awaiting confirmation are that the muscle works against elasticity of connective tissue, or that some displacement of fluid is involved, and raised hydrostatic pressure moves the light-organ back into the exposed position when muscle traction is released.

The light-organ muscle appears to originate anatomically in some instances from the maxillary division of the m. adductor mandibulae, and it may be derived ontogenetically from the latter (cf. Tchernavin, 1953). In this event, its innervation may be ascribed to the trigeminal nerve which supplies the $\mathrm{m}$. add. mandibulae (cf. Allis, I897). Apart from this muscle-innervation, the light organ is supplied directly by nerves which penetrate the enveloping tunics and sheaths to reach the photogenic tissue. I have identified these nerves in Astronesthes and Brauer (1904, 1908) observed nerves in the subocular light-organs of other stomiatoids. The origin of these nerves has still to be traced.

Examining young stomiatoids, Brauer (1904, I908) observed a lumen in the photogenic mass. In adults the photogenic tissue appears to be made up of convoluted cords of photocytes. Brauer suggested that this tissue is formed by invagination of surface epithelium, which then proliferates. Support is given to this hypothesis by the observations of Greene (1899), who actually found a process of this kind taking place in the development of skin photophores in the midshipman Porichthys. 
Living stomiatoids have been seen luminescing by a few observers. Haneda (1955) stated that the subocular light-organ of Astronesthes ijimai luminesces continuously, and that the luminous surface appears and disappears by rotating the organ. He suggests that luminous bacteria may be present, but in conversation recently he has discounted this idea. There is no doubt, from histological examination, that luminescence is autogenous, not bacterial.

Specimens of living Echiostoma have been observed to luminesce. Harvey (193I) found that the cheek organ, partially pink in life, flashed with a blue luminescence when the fish was handled. Following the injection of adrenaline, yellowish luminescence appeared in the photophores near the point of injection and soon spread to most of the other photophores. No luminescence appeared in the barbel. The cheek (subocular) organ continued to flash at intervals after the injection of adrenaline, but its rhythm and brightness were unaltered. Harvey asserted that the light appeared and disappeared in the subocular organ itself; the flashing was not due to unscreening of a continuously luminous surface. Beebe \& Crane (1939) have written that 'The postorbital is definitely under control of the fish, can be rolled down out of sight, and made to glow steadily or emit sharp flashes', and 'In the new Tactostoma ..., it apparently rotates forward and downward, instead of the usual downward'. Melanostomiatoids were observed from the 'Bathysphere' by Beebe (1935). The lateral serial organs usually glowed steadily; cheek organs, occasionally blinked and were rolled 'down' into sight.

In Chauliodus sloani, a weak continuous blue light has been observed on the ventral surface; the intensity of this light was not increased by mechanical stimulation. Following mechanical stimulation the serially arranged photophores luminesced, the response beginning near the point stimulated and spreading along the length of the fish; after a few seconds the light faded (Grassi, n.d.; Skowron, 1928).

Beebe (1935) has also observed luminescence in the barbel of various stomiatoids, and I found that the barbel of Leptostomias lighted momentarily after mechanical stimulation (Nicol, 1958).

The behaviour of a living stomiatoid (species unknown) under natural conditions has been reported by Clarke (1950). The fish was observed near the surface from the deck of a ship near the South Sandwich Islands. The stomiatoid fish, about $25 \mathrm{~cm}$ long, emitted a beam of varying intensity which shone directly forwards for a distance of about $0.6 \mathrm{~m}$. The fish was lurking $0 \cdot 6-\mathrm{I} \cdot 8 \mathrm{~m}$ below the surface, poised at an angle of $35-40^{\circ}$ from the horizontal, in which position the beam had an upward tilt. Occasionally, the fish swam around and with a quick action snapped at a cloud of krill above it.

Some miscellaneous references to luminescence in stomiatoids are given by Brauer (1908). These accounts do not clearly distinguish between the several kinds of light-organs. 
From the view point of functional anatomy some tentative conclusions may be induced from the miscellaneous observations now available dealing with the subocular light-organs of stomiatoids. Light-production is intracellular and autogenous; this follows from the histological evidence, and from Harvey's observation (193I). Luminescence is subject to direct nervous control; evidence includes periodic flashing and innervation of photocytes. The organ also can be rotated so that the light-emitting surface is hidden. Haneda (1955) states that this is a way of extinguishing the light. Mechanical screening, then, forms a second method of regulating emission. It may be that direct nervous action is concerned with protracted emission; rotation, with brief periodicity. An analogous situation is encountered in squids which have photophores provided with screens of chromatophores. The photophores are innervated directly and the chromatophores, by expansion and contraction, occlude and expose the luminous surface of the photophore. The surface of the subocular light-organ is white or coloured, reflecting and conspicuous against the black background of the head, and rotation provides a means of hiding this salient feature.

In all specimens in which the subocular light-organs were partly or wholly occluded, both organs in the fish were rotated to the same extent. It seems fairly certain that both members of the pair are operated in unison.

Luminescence appeared in the submental barbel of Leptostomias and in the subocular organ of Echiostoma after mechanical stimulation; in neither animal were the other photophores affected. Continuous light has been observed in the multitudinous small(simple) photophores of the outer corium of Chauliodus; the serial photophores lit up when the fish was stimulated mechanically. Beebe found that the injection of adrenaline induced luminescence in the serial photophores of Echiostoma without affecting other light organs.

Elsewhere, I have suggested (Nicol, 1957) that the serial photophores of teleosts are controlled by adrenergic nerve fibres of the sympathetic nervous system. When excited, the photophores of this system appear to respond as a unit. Since the other photophores of the head (viz. subocular, barbel) are not necessarily called into action at the same times, it is likely that their respective innervations are from a different source; indeed, the innervations of barbel and subocular light-organs may themselves be dissimilar from each other.

I would suggest that the dissimilar kinds of light-organs plus their different innervations signify that they are employed in several different ways. Stomiatoids are carnivores living below the level of effective light-penetration; some species are reported to come to the surface at night to feed (Beebe, 1926; Clarke, 1950). To judge from the frequency with which they are captured in nets, they are solitary hunters. In the dark depths where they live, much of the light needed for vision they must generate themselves. In shallow waters, in the neritic zone and in upper pelagic reaches, some fishes possess attractively shaped, coloured or actuated lures. In these regions, fishes make use of 
concealing coloration and warning coloration; males and females sometimes have dissimilar colour patterns concerned with occupation of territory and mating; some fishes advertise by suddenly exhibiting conspicuous fin-patches, etc. With these chromatic features are linked special behavioural characteristics. By analogy we might expect to find many of these roles, and perhaps others as well, performed by the light-organs of deep-sea fishes.

Bulbs on submental and dorsal tentacles may be fishing lures; this suggestion derives from analogy with the fishing tentacles of surface or neritic antennariids and lophiids, and the escal bulbs of deep-water Pediculati. The large subocular organs may be used as torches, for illuminating the surrounding water. The serially arranged photophores may permit the animals to recognize each other. The result may be mutual repulsion, thus keeping the fish spread out in hunting territories delimited by the intensity of the light and the distance at which it can be seen; or mutual attraction when the animals differ in sex. Possibly the same light-organs are used for different purposes; there may be patterns of signals and response, just as there are among inshore fishes, that allow the sexes to be distinguished. Although these problems seem rather intangible, there is a fair possibility that answers to them can be secured by various lines of attack, as the opportunities arise.

I would thank Mr A. C. G. Best for help with histological preparations.

\section{SUMMARY}

A histological study of the subocular light-organs of the following stomiatoid fishes has been carried out, viz. Stomias brevibarbatus, S. ferox, Chauliodus sloani, Astronesthes elucens, A. richardsoni, Photostomias guernei and Idiacanthus fasciola.

The subocular light-organ is a fairly large photophore lying just behind and below the eye. In all the species examined, except the last, it consists of a subspherical or elongate mass of photocytes, backed by an inner tunic and black pigment sheath. This assemblage, the light-organ proper, lies in the corium. The inner tunic sometimes contains reflecting material.

The photocytes are small polygonal cells, sometimes elongate and radiating outwards from the centre of the photogenic mass. They contain abundant acidophilic granules. In some species the ground cytoplasm is strongly basophilic.

The skin forms a clear window over the light-organ. There is a space between the dermis and the external face of the light-organ proper. Beneath the light-organ there is another layer of pigmented cells. A nerve penetrates the back of the light-organ to reach the photogenic tissue.

A long strap-like muscle, arising from the hyomandibula, runs down inside and beneath the light-organ to an insertion on the ventro-lateral or external 
face of the light-organ (except Idiacanthus). The function of this muscle is to pull the outer face of the light-organ downwards, in which position the lightemitting surface faces the ventral pigmented layer and is occluded.

In Idiacanthus the light-organ proper is similar. A pigmented layer lies above the light-organ, and the muscle passes underneath and across the external surface of the photogenic mass, to be inserted in the dorsal pigmented layer. The muscle pulls the dorsal pigmented layer down in front of the light-organ, like a screen.

From observations on the histology of the light-organs, and on living fish, some conclusions are drawn. Luminescence is autogenous and is subject to direct nervous control. In addition luminescence can be cut off by rotating the light-organ (or by pulling down the shutter in Idiacanthus). This action also conceals a conspicuous reflecting surface, apart from affecting luminescence. Control of the several kinds of light-organs of stomiatoids appears to be independent of each other, viz. regulation of tentacle bulb, subocular organs, and serial photophores, seemingly by different parts of the nervous system.

Suggested roles of luminescence are discussed.

\section{REFERENCES}

Allis, E. P., I897. The cranial muscles and cranial and first spinal nerves in Amia calva. F. Morph., Vol. I2, pp. 487-808.

BeEBe, W., 1926. The Arcturus Adventure. New York and London: Putnam's.

- 1935. Half Mile Down. London: John Lane.

Beebe, W. \& Crane, J., I939. Deep-sea fishes of the Bermuda Oceanographic Expeditions. Family Melanostomiatidae. Zoologica, N.Y., Vol. 24, pp. 65-238.

BRAUER, A., I904. Über die Leuchtorgane der Knochenfische. Verh. dtsch. zool. Ges., Bd. I4, pp. I6-35.

— 1908. Die Tiefsee-Fische. Anatomischer Teil. Wiss. Ergebn. 'Valdivia', Bd. I5 (T.II), $266 \mathrm{pp}$.

Clarke, R., 1950. The bathypelagic angler fish Ceratias hölbolli Kröyer. 'Discovery' Rep., Vol. 26, pp. I-32.

Ege, V., I918. Stomiatidae. Rep. Danish oceanogr. Exped. Medit., Vol. 2, Biol. A4, $28 \mathrm{pp}$.

Grassi, B., n.d. In Skowron, I928.

Greene, C. W., I899. The phosphorescent organs in the toad-fish, Porichthys notatus Girard. F. Morph., Vol. 15, pp. 667-96.

HANEDA, Y., I955. Luminous organisms of Japan and the Far East. In The Luminescence of Biological Systems, ed. Johnson, F. H., pp. 335-85. Wash., D.C.: Amer. Ass. Adv. Sci.

HaRveY, E. N., I93I. Stimulation by adrenaline of the luminescence of deep-sea fish. Zoologica, N.Y., Vol. 12, pp. 67-9.

Nicol, J. A. C., I957. Observations on photophores and luminescence in the teleost Porichthys. Quart. F. micr. Sci., Vol. 98, pp. 179-88.

— 1958. Observations on luminescence in pelagic animals. F. mar. biol. Ass. U.K., Vol. 37, pp. 705-72. 
PARR, A. E., 1927. The stomiatoid fishes of the suborder Gymnophotodermi (Astronesthidae, Metanostomiatidae, Idiacanthidae). With a complete review of the species. Bull. Bingham oceanogr. Coll., Vol. 3, Art. 2, I23 pp.

Regan, C. J. \& Trewavas, E., I929. The fishes of the families Astronesthidae and Chauliodontidae. 'Dana' Rep., Vol. 2, No. 5, 39 pp.

Skowron, S., 1928. Über das Leuchten des Tiefseefisches. Chauliodus sloanii. Biol. Zbl., Bd. 48, pp. 680-5.

Tchernavin, V. V., I953. The Feeding Mechanisms of a Deep Sea Fish Chauliodus sloani Schneider. ror pp. London: Brit. Mus. (Nat. Hist.).

Zugmayer, E., I9II. Poissons provenant des campagnes du yacht Princesse-Alice. Résult. Camp. sci. Monaco, Fasc. 35, I74 pp. 